\title{
Effect of heat on loofah gourd seeds chemical composition and fatty acids of raw seeds
}

\author{
Sunday Dairo FESTUS AYODEJI ${ }^{1 *}$, Fasuy OLUDARE AYODEJI ${ }^{1}$, \\ Emmanuel ILESANMI ADEYEYE ${ }^{2}$ and Pius AYOKA AYE ${ }^{1}$ \\ ${ }^{I}$ Department of Animal Production \& Health Sciences, University of Ado-Ekiti, Ado-Ekiti, Nigeria. \\ ${ }^{2}$ Department of Chemistry, University of Ado-Ekiti, Ado-Ekiti, Nigeria. \\ "Corresponding author, E-mail: fasdairo@yahoo.com
}

\begin{abstract}
Dehulled loofah gourd seeds (DLGS), Luffah cylindrica was divided into three parts namely; raw (DLGSR), boiled for $5 \mathrm{~min}$ at $100{ }^{\circ} \mathrm{C}$ (DLGSB) and cooked for $30 \mathrm{~min}$ (DGLSC). Proximate composition, amino acids, amino acid scores and energy were determined in DLGSR, DLGSB and DLGSC and fatty acids constituents only in DLGSR on dry matter basis. Crude protein content of DLGSB and DLGSC were similar and significantly lower $(\mathrm{p}<0.05)$ than DLGSR while crude fibre, carbohydrate, ash, and the ether extract were not (p>0.05). Glutamic acid (Glu), aspartic acid (Asp), leucine (Leu), arginine (Arg), lysine (Lys), valine (Val) and phenylalanine (Phe) were concentrated in DLGSR in the order listed. Arg, Thr, Asp, Glu, Pro,Gly and Ala were significantly highest $(\mathrm{p}<0.05)$ in DLGSC while Lys, Asp and Ser were highest $(\mathrm{p}<0.05)$ in DLGSR and Gly and Tyr in DLGSB. The percent total non-essential amino acid (TNEAA) and the protein efficiency ratio (P-PER) were highest ( $p>0.05$ ) in raw and boiled seeds respectively. The limiting amino acid in the samples was Met+Cyst. The fatty acid constituents were myristic, palmitic, palmitoleic, stearic, oleic, linoleic and arachidic acid. DLGSR contained $99.1 \%$ total fatty acids, $31.4 \%$ total saturated fatty acids, $67.7 \%$ total unsaturated fatty acids. Loofah gourd seed is a good potential vegetable protein source as food/feed.
\end{abstract}

(C) 2013 International Formulae Group. All rights reserved.

Keywords: Boiled, cooked, dehulled, proximate, energy.

\section{INTRODUCTION}

Protein is the prevalent nutrient that is of importance and most deficient in the nutrition of man and farm animals. Vegetables or plants have been the main source of protein in the diets of farm animals both monogastrics and ruminants. However, the "food-feed" competition placed a high premium on some quality vegetable protein sources like soybean, groundnut, peanut and cowpea which over the years have been the traditional quality vegetable protein sources in animal feed. The pressure on these ingredients in the last three to four decades necessitated the need to explore other vegetable protein sources that are of less relevance to man for food. The various ecological zones of the world are naturally endowed with vegetables or plants that are yet to be maximally explored and which could be of tremendous application in human and animal foods and/or remedies. The nutritional interest in some of these plants of less importance to man is taken more seriously now, against the backdrop of 
dwindling availability of the conventional ingredients as a result of exhorbitant price due to the "food-feed" competition. Some pulses such as Canavalia ensiformis (jackbeans), Cajanus cajan (pigeon pea), Caesalpina pulcherima and cucurbits have been reported to be promising in this respect (Agbede, 2004; Dairo, 2008). Among the cucurbiticae group are the seeds of Citrullus lanatus and Cucumeropsis edulis which are used for commercial vegetable oil production in the recent past (Omidiji, 1977). These group of cucurbits and Telfaria species have been found to be of good sources of oil and protein in melon soup consumed most especially in the West African Sub-region. However, loofah gourd seeds which belong to the cucurbiticae family have been reported by Dairo et al. (2007) and Dairo (2008) to contain anti-nutritional compounds such as tannin, oxalate and phytic acid or (myoinositolhexaphosphate). It has been identified as one of the promising plant of less importance to man.

Quite a number of information is available on the amino and fatty acids composition of some of the earlier mentioned unconventional legumes and cucurbits (Abiodun, 1998; Hassan et al., 2008). However, there is paucity of information on the amino acid and fatty acid contents of Luffa cylindrica gourd seeds. This study was therefore carried out to determine the amino acid content of dehulled loofah (Luffa cylindrica) gourd seeds, the fatty acid content and the effects of boiling and cooking on its amino acids constituents .

\section{MATERIALS AND METHODS}

Loofah gourd seeds were harvested during the months of February and early April which is the dry season of the year in Ado-Ekiti, Southwestern Nigeria. The town is situated in the rain forest zone on latitude $7^{\circ}$ $40^{\prime}$ North of the equator and longitude $5^{\circ} 15^{\prime}$ East of the Greenwich Meridian. The cucumber shaped fruits were broken and the sponge inside sliced open to remove the seeds that are black in colour with hard seed coat.
They were dried and dehulled manually after soaking in warm water of initial temperature of about $80{ }^{\circ} \mathrm{C}$ and left overnight for about 10-12 h.

The dehulled seed was sun dried for a period of three days to about $120 \mathrm{~g} / \mathrm{kg}$ moisture content. The sun dried seed was divided into three equal parts. The first part was not treated in any form and was labelled as dehulled raw loofah gourd seed (DLGSR). About $500 \mathrm{~g}$ of the second part of the dehulled seed was put in a small bag made of cheese cloth and immersed in already boiling water at $100{ }^{\circ} \mathrm{C}$ for five minutes. The seeds were then sun dried in an open terrain for three days and labelled dehulled boiled loofah gourd seed (DLGSB). The third part was cooked in boiling water for $30 \mathrm{~min}$. The seed was also sun dried for three days and labelled dehulled cooked loofah gourd seed (DLGSC). Each sample was milled in a Laboratory Hammer mill (DIETZ,7311 Dettingen-Teck, West Germany) and stored separately in a dried one litre transparent sample bottle and kept for proximate and amino acid analyses.

The moisture or dry matter were determined by drying in an oven at $105{ }^{\circ} \mathrm{C}$ until a constant weight was obtained for each sample (AOAC, 2005). $2 \mathrm{~g}$ of the milled loofah gourd seed sample was weighed into an extraction thimble. The sample was defatted for about $6 \mathrm{~h}$ in a Soxhlet apparatus using petroleum ether of Analar grade (British Drug House, London) with a boiling range of $40-$ $60{ }^{\circ} \mathrm{C}$ and ash, fibre, protein and nitrogen free extractives (NFE) were determined as described by AOAC (2005). The total fatty acids in the sample was obtained by multiplying the crude fat by a factor of 0.80 (Weihrauch et al., 1977). The total energy value of each sample was calculated by multiplying the crude fat, protein and the NFE by Atwater (1910) factors of 37.6, 16.7 and 16.7 respectively and the proportion of each was equally determined.

Thirty five (35) $\mathrm{mg}$ of the defatted sample was weighed into glass ampoules to which was added $7 \mathrm{ml}$ of $6 \mathrm{~mol} / \mathrm{l} \mathrm{HCl}$. Nitrogen gas was passed through the sample 
in the glass ampoules to eliminate oxygen gas that may possibly oxidize the amino acids during hydrolysis. The glass ampoules were later sealed in a Bunsen burner flame and put in an oven for $22 \mathrm{~h}$ at $105{ }^{\circ} \mathrm{C}$. After cooling, each of the glass ampoule was broken open at the tip and the content filtered. The filterate was evaporated to dryness at $40{ }^{\circ} \mathrm{C}$ under vacuum in a rotary evaporator. The residue in each sample was dissolved in $5 \mathrm{ml}$ acetate buffer, stored in plastic specimen bottle and kept in the deep freezer for analysis as described by Adeyeye and Afolabi (2004).

The ion-exchange chromatography method as described by FAO/WHO (1991) was employed in the amino acids analyses. 5$10 \mu \mathrm{l}$ of each of the samples were loaded and dispensed into the catridge of Technicon Sequential Multisample Amino Acid Analyser (TSM) (Technicon Instruments Corporation, NewYork). The analyzer has a column flow rate of $0.50 \mathrm{~mL} / \mathrm{min}$ at $60{ }^{\circ} \mathrm{C}$ with $\pm 3 \%$ reproducibility and is designed to separate and analyse free acidic, basic and neutral amino acids in the hydrolysate which lasted for about $76 \mathrm{~min}$ for each sample. The determination of the amino acids was done in triplicate and the average values used for each amino acid calculation. Tryptophan was not determined in this study. The amino acid score was calculated using the formula below with egg as the reference and thereafter the amino acid with the highest deficiency was noted. The deficiency is substracted from 100 as described by Crampton and Harris (1969) to obtain the least amino acid score or the limiting amino acid in the dehulled loofah gourd seed samples.

Amino acid score $=\mathrm{mg}$ amino acid per $\mathrm{g}$ of test diet/ mg amino acid per $\mathrm{g}$ of egg

The predicted protein efficiency ratio (P-PER) was calculated using the equation according to Alsmeyer et al. (1974):

P-PER $=-0.468+0.454($ Leu $)-0.105($ Tyr $)$

The oil extract was converted to the methyl ester as described by Hall and Ledward (1982). The fatty acids of the methyl esters were analyzed using a PYE Unicam 304 gas chromatography (PYE Unicam, Cambridge, UK). It was fitted with flame ionization detector and a PYE Unicam PU4810 computing integrator. The initial temperature of the column was $150{ }^{\circ} \mathrm{C}$ which rose at $5{ }^{\circ} \mathrm{C} / \mathrm{min}$ to a final temperature of 220 ${ }^{\circ} \mathrm{C}$. The injection port and the detector were maintained at $220{ }^{\circ} \mathrm{C}$ and $250{ }^{\circ} \mathrm{C}$ respectively. The carrier gas used was helium. The esters were separated using a polar (25QC3/BPI-0.5) capillary column $(25.00 \mathrm{~mm} \times 0.33 \mathrm{~mm}$; SGE Scientific Glass Engineering Co., UK). The peaks of each fatty acid was compared with standard fatty acid methyl esters from Sigma Chemical Co. (St Louis, MO, USA)

All the results except fatty acids values of the raw dehulled sample were subjected to one way ANOVA. The means, and coefficient of variation $(\mathrm{CV})$ in percent were also determined using the GLM linear Model of SAS (1987).

\section{RESULTS AND DISCUSION}

The proximate composition of the DLGSR, DLGSB and DLGSC are presented in Table 1. The crude protein value was similar in DLGSC and DLGSB but significantly $(\mathrm{p}<0.05)$ lower than DLGSR. The CF, EE, ash, nitrogen free extractives (NFE) and dry matter were not significantly affected $(p>0.05)$ by the heat treatment on the loofah gourd seeds. The proximate composition of loofah gourd seed compared favourably with the values of $350-390 \mathrm{~g} / \mathrm{kg}$ $\mathrm{CP}, 300-461 \mathrm{~g} / \mathrm{kg}$ crude fat, $20-50 \mathrm{~g} / \mathrm{kg}$ ash and $18.6 \mathrm{~g} / \mathrm{kg}$ fibre reported in literature (Hassan et al., 2008 ; Olaofe et al., 2009) but higher in dry matter and NFE content as indicated in the findings of Olaofe et al. (2009). As a result of closeness in values of the crude protein content of loofah gourd seeds and some oil seeds such as soybean, groundnut, coconut, palm kernel and cotton seeds, it has a great potential for use in human and animal diets. Presently, loofah gourd seeds do not have any competitive industrial use hence could be developed to maximally harness its nutritive potentials.

The metabolizable energy values and the proportion contributed by protein, fat and carbohydrate in DLGSR, DLGSB and DLGSC are shown in Table 2. The total energy in DLGSR was numerically higher than same values obtained for DLGSB and 
DLGSC by $0.43 \%$. The proportion of energy contributed by NFE was lowest in DLGSR. This is because the NFE values in DLGSR was lower than those of DLGSB and DLGSC. However, the values were not significantly $(p>0.05)$ afffected by heat treatment. The energy content 2432.37 $2442.85 \mathrm{KJ} / \mathrm{kg}$ compared favourably with that of other vegetable protein sources such as reported by Olaofe et al. (1993) for Cajanus cajan and Leganaria sciceraria (Olaofe et al., 2009). This is possible because of the ether extract component of the seed hence loofah gourd seeds doubles as a potential energy and protein sources.

Table 3 presents the amino acid composition of the dehulled raw, boiled and cooked loofah gourd seeds. The values of Lys, Asp and Ser were significantly higher $(\mathrm{p}<0.05)$ in DLGSR than DGLSB and DGLSC. Threonine recorded similar values in DLGSR and DLGSB but its value was higher $(p<0.05)$ in DLGSC. Arg value significantly $(p<0.05)$ increased in the order of DLGSC > DLGSR > DLGSB. Other amino acids determined namely; Val, Ile, Phe and His were not significantly $(p>0.05)$ affected by the heat treatment on the loofah gourd seeds.

Glu, Asp, Leu and Arg were the most concentrated amino acids in DLGSR while Met+Cys were the least. Arg content of DLGSR was not as concentrated as in other cucurbiticaea family which also agreed with the report of Badifu and Ogunsua (1991), Aremu et al. (2006) and Olaofe et al. (2009) but contrary to the findings of Hassan et al. (2008). Met+Cys were the limiting amino acids in both the raw (DLGSR) and the heat treated loofah gourd seeds namely DLGSB and DLGSC (Table 5). The limiting amino acids in legumes and some other oil seeds include some of the sulphur containing ones particularly Cys and Met which can be corrected for (Silano et al., 1982). Therefore, heat treated loofah gourd seeds could be included in animal feed and supplemented with other quality vegetable protein sources such as soybean or groundnut cake. Supplementation of loofah gourd seed when used in livestock feed with animal protein sources such as blood meal that are rich in cystine and methionine may enhance its use as a substitute for expensive vegetable protein sources. This statement is demonstrated in the study of Dairo (2008) who reported a 5\% tolerable inclusion level of raw loofah gourd seed meal in rabbit diet inspite of the presence of some anti-nutrients such as saponin, oxalate and phytin.

The total amino acids (TAA) in the raw loofah gourd seeds and the heat treated samples are presented in Table 4. Total basic amino acids (TBAA) was similar for DLGSB and DLGSC $(135 \pm 0.03 \mathrm{mg} / \mathrm{gcp})$ but significantly higher $(\mathrm{p}<0.05)$ in DLGSR $(168 \pm 2.35 \mathrm{mg} / \mathrm{gcp})$. Total non-essential amino acid (TNEAA) in DLGSC $(417 \pm 1.31$ $\mathrm{mg} / \mathrm{gcp}$ ) was also similar in value to that of DLGSB but higher $(\mathrm{p}<0.05)$ than DLGSR $(373 \pm 1.04 \mathrm{mg} / \mathrm{gcp})$. This trend was expectedly followed by $\%$ TNEAA. Percent total essential amino acid (TEAA)+ His was similar in DLSGR and DLGSB and the values were significantly higher $(p<0.05)$ than what was obtained in DLGSC. The TAA of DLGSR $(769.6 \pm 6.78 \mathrm{mg} / \mathrm{gcp})$ is comparable with the values of 703 - $917 \mathrm{mg} / \mathrm{g} \mathrm{cp}$ reported for African yam bean by Oshodi et al. (1995). The TEAA is lower in Luffah cylindrica $(324 \pm 1.30 \quad-385 \pm 5.74 \mathrm{mg} / \mathrm{gcp})$ than the values for soybean $(444 \mathrm{mg} / \mathrm{g} \mathrm{cp}$ ) (Kuri et al., 1991) pigeon pea (452 mg/g cp) (Nwokolo, 1987) and Cajanus cajan (426 $\mathrm{mg} / \mathrm{g} \mathrm{cp}$ ) (Olaofe et al., 1993) but comparable in values to pumpkin seed (396 mg/g cp) (Aisegbu, 1987) and Leganaria sciceraria (327 mg/g cp) (Olaofe et al., 2009). Consequently, the quality of amino acids in the DLGSR is lower than soybean, cowpea, pigeon pea but comparable with pumpkin seed. The mean values obtained in this study were above the recommended values (when converted) for Leu, Lys, Val (4.2 g/16g N 
protein each), Thr and Phe (2.8 g/16 g N protein each) (FAO/WHO, 1991) which further attest to Luffah cylindrica seeds as a promising plant protein source in diets of farm animals and human. The percent TEAA with or without histidine indicated that DLGSR is more concentrated in the essential amino acids which further supports its nutritive potentials as food or feed. The crude protein results of the raw and heat treated loofah gourd seeds indicated a slight variation. The heat effect on the DLGSB and DLGSC significantly lowered their crude protein contents even though this was expected to be more pronounced in the cooked sample because of the length of heat application. The reduction may have been due to denaturization of some of the protein content of DLGSB and DLGSC. Consequently, some of the proteins in the boiled and cooked samples might have been destroyed hence loss of the nitrogen which is the determinant for crude protein.

Five of the amino acids were not affected by the application of heat treatment namely Leu, Ile, Val, Phe, His while others showed remarkable differences $(p<0.05)$. Lys has been reported to be very susceptible to heat damage in the presence of moisture (Muller and Tobin, 1980). It is also expected that most of the amino acids in the DLGSB and DLGSC would be reduced in values due to possible Maillard reaction which is a condensation between the carbonyl group of reducing sugar and the free amino group in the test samples of DLGSB and DLGSC. This reaction would subsequently undergo Amadori rearrangement and browning followed. The extent of this reaction and effects on the amino acids has been reported to be dependent on factors such as temperature, $\mathrm{pH}$, concentration of the reactants and the period of exposure to heat for the individual amino acids (Muller and Tobin, 1980). In this study, boiling of the DLGSB samples was carried out for five minutes in water at boiling point $\left(100{ }^{\circ} \mathrm{C}\right)$ while DLGSC was cooked for much longer period at $30 \mathrm{~min}$. This may have effected a change in some of the L- amino acid to their corresponding D- amino acid.

The amino acid score of the essential amino acids in loofah gourd seeds is shown in Table 5. Leu, Val, Lys, His, Met+Cys were all significantly $(p<0.05)$ affected by the heat treatment of the seeds. Leu, Val and Lys followed the same trend of DLGSR > DLGSB >DLGSC while Ile, Thr and Phe did not $(p>0.05)$. The values of Arg, Tyr and Me+Cys were highest $(p<0.05)$ in DLGSC than either DLGSB or DLGSR whereas Thr and Phe were not affected by the heat treatment $(\mathrm{p}>0.05)$.

Table 6 shows the fatty acids contents, monounsaturated fatty acid (MUFA), and diunsaturated fatty acid (DUFA) of the loofah gourd seeds. It contained myristic, palmitic, palmitoleic, stearic, oleic, linoleic and arachidonic acids. The values of unsaturated fatty acid (UFA) obtained in this study compared favourably with that of soybean $(67.7 \%)$ but lower in saturated fatty acids (SFA) (12.4\%) as reported by Holland et al. (1991). The result suggests DLGSR as a good source of UFA with good health implication to man and it compares with soybean. This is because SFA had been implicated as one of the main cause of coronary heart disease in man (Bender, 1992). Studies have implicated myristic acid (C14:0) and palmitic acid (C16:0) to be responsible for the increase in blood cholesterol level by becoming about 46 $\%$ component part of the low-density lipoproteins (LDL) and hence a dietary risk factor in human nutrition (Bender, 1992). Stearic acid (C18:0) in DLGSR is comparable in values to palmitic acid (C16:0) however, the former have been reported to be convertible to oleic acid (C18:1) which is a monounsaturated acid. Linoleic acid (C18:2) is of substantial concentration in loofah gourd seed. This puts the plant in an advantageous position because linoleic acid is one of the essential fatty acids. 
Table 1: Proximate composition of dehulled raw, boiled and cooked loofah gourd seeds on dry matter basis $(\mathrm{g} / \mathrm{kg})$.

\begin{tabular}{lccc}
\hline Treated Seed & DLGSR \pm SD & DLGSB \pm SD & DLGSC \pm SD \\
\hline Dry Matter & $970.8 \pm 1.02$ & $970.7 \pm 0.36$ & $970.7 \pm 0.36$ \\
Crude Protein & $375.0 \pm 0.02^{\mathrm{a}}$ & $371.0 \pm 0.003^{\mathrm{b}}$ & $371.0 \pm 0.00^{\mathrm{b}}$ \\
Crude Fibre & $29.9 \pm 0.15$ & $28.6 \pm 0.08$ & $28.6 \pm 0.08$ \\
Fat & $423.0 \pm 0.41$ & $427.0 \pm 0.40$ & $427.0 \pm 0.40$ \\
Ash & $42.70 \pm 0.16$ & $42.7 \pm 0.01$ & $42.7 \pm 0.01$ \\
Nitrogen Free Extractives & $133.4 .0 \pm 0.12$ & $126.7 \pm 0.05$ & $126.7 \pm 0.05$ \\
\hline
\end{tabular}

$a, b:$ Mean values in row without letter in common are different at $p<0.05$.

Table 2: Energy values as contributed by protein, fat and carbohydrate in dehulled raw, boiled, and cooked loofah gourrd seed.

\begin{tabular}{lccc}
\hline Parameter & DLGSR & DLGSB & DLGSC \\
\hline Total energy $\mathrm{KJ} / \mathrm{Kg}$ & $2442.85 \pm 12.0$ & $2432.37 \pm 9.0$ & $2432.37 \pm 10.1$ \\
Proportion of total energy due to protein (\%) & $25.6 \pm .01$ & $25.47 \pm .04$ & $25.47 \pm 0.0$ \\
Proportion of total energy due to fat (\%) & $65.70 \pm 1.2$ & $65.37 \pm 0.8$ & $65.37 \pm 0.3$ \\
Proportion of total energy due to Nitrogen Free & $8.66 \pm 0.1$ & $9.16 \pm 0.3$ & $9.16 \pm 0.2$ \\
Extractives (\%) & & & \\
\hline
\end{tabular}

Table 3: Amino acid composition of dehulled raw, boiled and cooked loofah gourd seeds ( $\mathrm{mg} / \mathrm{g}$ crude protein).

\begin{tabular}{lccc}
\hline Amino acids & DLGSR & DLGSB & DLGSC \\
\hline Leu & $75.1 \pm 1.28$ & $52.7 \pm 0.00$ & $61.7 \pm 0.01$ \\
Ile & $34.6 \pm 0.24$ & $30.1 \pm 0.001$ & $29.8 \pm 0.01$ \\
Val & $58.2 \pm 0.91$ & $46.1 \pm 0.003$ & $38.5 \pm 0.01$ \\
Thr & $27.6 \pm 0.03^{\mathrm{b}}$ & $28.1 \pm 0.09^{\mathrm{b}}$ & $30.3 \pm 0.01^{\mathrm{a}}$ \\
Phe & $50.4 \pm 0.01$ & $47.6 \pm 0.01$ & $49.8 \pm 0.01$ \\
Lys & $63.6 \pm 0.38^{\mathrm{a}}$ & $48.2 \pm 0.01^{\mathrm{b}}$ & $39.9 \pm 0.01^{\mathrm{b}}$ \\
His & $37.7 \pm 0.74$ & $26.5 \pm 0.01$ & $26.43 \pm 0.01$ \\
Met & $9.40 \pm 0.14$ & $13.1 \pm 0.01$ & $14.9 \pm 0.003$ \\
Met + Cys & $11.8 \pm 0.09$ & $16.95 \pm 0.01$ & $19.7 \pm 0.01$ \\
Arg & $66.6 \pm 0.11^{\mathrm{b}}$ & $60.6 \pm 0.01^{\mathrm{c}}$ & $71.6 \pm 0.03^{\mathrm{a}}$ \\
Asp & $91.7 \pm 0.14^{\mathrm{a}}$ & $81.5 \pm 0.01^{\mathrm{c}}$ & $88.1 \pm 0.003^{\mathrm{b}}$ \\
Ser & $36.9 \pm 0.01^{\mathrm{a}}$ & $36.2 \pm 0.01^{\mathrm{b}}$ & $34.7 \pm 0.01^{\mathrm{c}}$ \\
Glu & $111 \pm 0.06^{\mathrm{c}}$ & $124 \pm 0.01^{\mathrm{b}}$ & $134 \pm 0.25^{\mathrm{a}}$ \\
Pro & $27.1 \pm 0.02^{\mathrm{c}}$ & $28.6 \pm 0.01^{\mathrm{b}}$ & $31.5 \pm 0.01^{\mathrm{a}}$ \\
Gly & $19.8 \pm 0.01^{\mathrm{b}}$ & $35.4 \pm 0.01^{\mathrm{a}}$ & $24.1 \pm 0.01^{\mathrm{a}}$ \\
Ala & $20.8 \pm 0.003^{\mathrm{a}}$ & $22.2 \pm 0.01^{\mathrm{b}}$ & $25.4 \pm 0.003^{\mathrm{b}}$ \\
Cys & $4.8 \pm 0.02^{\mathrm{c}}$ & $7.7 \pm 0.01^{\mathrm{b}}$ & $9.6 \pm 0.01^{\mathrm{a}}$ \\
Tyr & $22.5 \pm 0.003^{\mathrm{c}}$ & $39.7 \pm 0.01^{\mathrm{a}}$ & $31.4 \pm 0.003^{\mathrm{b}}$ \\
\hline \multicolumn{4}{c}{ a,b,c: Mean values in row without letter in common are different at $p<0.05}$.
\end{tabular}


Table 4: Sum of total amino acids, acidic, basic, essential and non-essential amino acids and their percentages in dehulled raw, boiled and cooked loofah gourd seeds (mg/g crude protein).

\begin{tabular}{lccc}
\hline Parameters & DLGSR \pm SD & DLGSB \pm SD & DLGSC \pm SD \\
\hline TAA & $769.6 \pm 6.78$ & $745.2 \pm 0.33$ & $737.4 \pm 0.11$ \\
TAAA & $590 \pm 4.43$ & $593 \pm 0.02$ & $605 \pm 0.17$ \\
TBAA & $168 \pm 2.35^{\mathrm{a}}$ & $135 \pm 0.03^{\mathrm{b}}$ & $136 \pm 0.05^{\mathrm{b}}$ \\
TEAA+His & $423 \pm 7.02$ & $353 \pm 0.01$ & $348 \pm 1.30$ \\
TEAA & $385 \pm 5.74$ & $326 \pm 0.003$ & $324 \pm 1.30$ \\
TNEAA & $373 \pm 1.04^{\mathrm{b}}$ & $402 \pm 0.03^{\mathrm{a}}$ & $417 \pm 1.31^{\mathrm{a}}$ \\
\%TNEAA & $49.4 \pm 3.21^{\mathrm{b}}$ & $55.2 \pm 0.02^{\mathrm{a}}$ & $56.3 \pm 1.76^{\mathrm{a}}$ \\
\%TEAA & $50.7 \pm 3.21^{\mathrm{a}}$ & $44.8 \pm 0.02^{\mathrm{b}}$ & $44.9 \pm 1.30^{\mathrm{b}}$ \\
\%TEAA+His & $55.5 \pm 4.52^{\mathrm{a}}$ & $48.4 \pm 0.01^{\mathrm{ab}}$ & $47.0 \pm 0.56^{\mathrm{b}}$ \\
P-PER & $32.2 \pm 3.0^{\mathrm{a}}$ & $20.2 \pm 1.6^{\mathrm{c}}$ & $25.2 \pm 2.2^{\mathrm{b}}$ \\
\hline
\end{tabular}

$a, b, c$ : Mean values in row without letter in common are different at $p<0.05$.

Table 5: Essential amino acid score of dehulled raw, boiled and cooked loofah gourd seeds.

\begin{tabular}{lccc}
\hline Amino acids & DLGSR \pm SD & DLGSB \pm SD & DLGSC \pm SD \\
\hline Leu & $93.6 \pm 0.91^{\mathrm{a}}$ & $67.1 \pm 0.98^{\mathrm{b}}$ & $67.2 \pm 1.02^{\mathrm{b}}$ \\
Ile & $41.3 \pm 0.31$ & $37.3 \pm 0.02$ & $37.0 \pm 0.34$ \\
Val & $90.7 \pm 0.00^{\mathrm{a}}$ & $52.6 \pm 0.67^{\mathrm{b}}$ & $52.5 \pm 1.13^{\mathrm{b}}$ \\
Thr & $57.4 \pm 0.07$ & $61.4 \pm 1.05$ & $61.4 \pm 0.37$ \\
Phe & $86.2 \pm 2.22$ & $79.0 \pm 1.02$ & $78.9 \pm 1.19$ \\
Lys & $95.0 \pm 2.08^{\mathrm{a}}$ & $55.4 \pm 0.78^{\mathrm{b}}$ & $55.3 \pm 0.31^{\mathrm{b}}$ \\
His & $215 \pm 8.31^{\mathrm{a}}$ & $115 \pm 2.37^{\mathrm{b}}$ & $286 \pm 3.66^{\mathrm{a}}$ \\
Met + Cys & $22.99 \pm 0.25$ & $39.99 \pm 0.02$ & $23.7 \pm 0.05$ \\
Arg & $103 \pm 0.99^{\mathrm{b}}$ & $112 \pm 1.74^{\mathrm{a}}$ & $111 \pm 2.01^{\mathrm{a}}$ \\
Tyr & $50.0 \pm 1.23^{\mathrm{b}}$ & $50.0 \pm 0.8^{\mathrm{b}}$ & $69.8 \pm 0.45^{\mathrm{a}}$ \\
Cys & $7.38 \pm 0.46^{\mathrm{b}}$ & $7.38 \pm 0.01^{\mathrm{b}}$ & $14.8 \pm 0.00^{\mathrm{a}}$ \\
\hline \multicolumn{1}{c}{ a, b: Mean values in row without letter in common are different at $p<0.05}$.
\end{tabular}

Table 6: Fatty acid composition of raw loofah gourd seeds (\%).

\begin{tabular}{lc}
\hline Fatty acid & Mean value \pm SD \\
\hline Myristic acid : C14:0 & $0.26 \pm 0.02$ \\
Palmitic acid : C16:0 & $15.3 \pm 0.15$ \\
Palmitoleic acid : C16:1 & $1.22 \pm 0.01$ \\
Stearic acid : C18:0 & $15.2 \pm 0.01$ \\
Oleic acid : C18:1 & $15.3 \pm 0.01$ \\
Linoleic acid : C18:2 & $51.2 \pm 0.01$ \\
Arachidic acid : C20:0 & $0.62 \pm 0.01$ \\
Total fatty acid & $99.1 \pm 2.18$ \\
Total saturated fatty acids & $31.4 \pm 0.11$ \\
Total unsaturated fatty acids & $67.7 \pm 0.45$ \\
$\%$ Saturated fatty acids & $31.7 \pm 0.07$ \\
$\%$ Unsaturated fatty acids & $68.3 \pm 0.03$ \\
\hline SD $=$ Standard deviation. &
\end{tabular}




\section{Conclusion}

Conclusively, whole loofah gourd seed is a potential vegetable protein source in animal feed. It could be supplemented with cereals or other amino acid sources rich in cystine and methionine to further enhnace its utilization. Its relatively high level of UFA could be explored for consumption in humans and other industrial use.

\section{ACKNOWLEDGMENTS}

The authors are grateful to Mrs Olunfunmilayo Jadesola Dairo for financial support for this study and Ms Afolabi and Osayomi for procuring and dehulling the loofah gourd seeds. We also appreciated the assistance of Mr.Femi Omotayo, the plant taxonomist in the Department of Plant Science, University of Ado-Ekiti for the identification of loofah gourd plant.

\section{REFERENCES}

Abiodun JA. 1998. Legumes. In Nutritional Quality of Plant Foods, Osagie AU, Eka OU (eds). Published by the Post harvest Research Unit, Department of Biochemistry, University of Benin: Benin City, Nigeria ; 53 - 83.

Adeyeye EI, Afolabi EO. 2004. Amino acid composition of three different types of land snails consumed in Nigeria. $F d$. Chem., 85: 535 - 539.

Agbede JO. 2004. Compositional studies of differently processed ornamental seed flour Caesalpina pulcherima. Pak. J. Nutr., 3(4): 222 - 227.

Aisegbu JE. 1987. Some biochemical evaluation of fluted pumpkin seed. J. Sci. Food Agric., 40: 151-155.

Alsmeyer RH, Cunningham AE, Happich ML. 1974. Equations to predict PER from amino acid analysis. $F d$. Technol., 28: 34-38.

AOAC. 2005. Official Methods of Analysis (18th edn). AOAC, International Maryland: USA.

Aremu MO, Olaofe O, Akintayo ET. 2006. A comparative study on the chemical and amino acid composition of some Nigerian under-utilized legume flours. Pak. J. Nutr., 5(1): 34 - 38.

Atwater WO. 1910. Principles of nutrition and nutritive values of food. United States Farmers' Bulletin $N^{\circ} 142$.

Badifu GIO, Ogunsua AO. 1991. Chemical composition of kernels from some species of Cucurbitaceae grown in Nigeria. Plant Foods for Human Nutrition, 41: 35 - 44.

Bender A. 1992. Meat and Meat Products in Human Nutrition in Developing Countries ; FAO Food and Nutrition $N^{\circ}$ 53. FAO: Rome, Italy.

Crampton EW, Harris LE. 1969. Applied Animal Nutrition (2nd edn). WH Freeman and Company: San Francisco; 94 - 96

Dairo FAS, Aye PA, Oluwasola TA. 2007. Some functional properties of loofah gourd (Luffah cylindrica L. M. J. Roem) seed. J. Food Agric. \& Environ., 5(1): 97 -101 .

Dairo FAS. 2008. Performance and haematological evaluation of weaner rabbits fed loofah gourd seed meal (Luffa cylindrica \{ M.J.Roem\}). African Journal of Food, Agriculture, Nutrition \& Development, 8(4): 451 - 463.

FAO/WHO. 1991. FAO/WHO, Protein quality evaluation, Report of joint FAO/WHO Expert consultation, FAO Food and Nutrition $\mathrm{N}^{\circ}$ 51, Rome, Italy.

Hall GM, Ledward DA. 1982. Silage from tropical fish 3. Lipid behaviour. Int. J. Food Sci. \& Tech., 21: 45- 54.

Hassan LG, Sani NA, Dangoggo SM. 2008. Nutrtional value of bottle gourd Lagenaria sciceraria seeds. Global Journal of Pure \& Applied Scienes, 14(3): $301-306$.

Holland B, Welch AA, Unwin ID, Buss DH, Paul AA, Southgate DA, McCance T, Widdowson's. 1991. The composition of foods. 5th ed. Cambridge,United Kingdom: Royal Society of Chemistry, Ministry of Agriculture, Fisheries and Food.

Kuri EY, Rao KS, Kaluwi C, Jones GP, Rivett DE. 1991. Chemical composition 
of Momodica charantis L. Fruits. J. Agric. \& Food Chem., 39: 1762-1763.

Muller HE, Tobin G. 1980. Nutrition and Food Processing. Crown Helm: London ; 249 - 260.

Nwokolo E. $1987 . \quad$ Nutritional evaluation of pigeon pea meal. Plant Foods for Human Nutrition, 37: 283 290.

Olaofe O, Umar YO, Adediran GO. 1993. The effect of nematicides on the nutritive value and functional properties of cowpea seeds (Vigna unguicalata L. walp). Fd Chem., 46(4): 337 - 342 .

Olaofe O, Faleye FJ, Adeniji AA, Akinsola AF. 2009. Amino acid and mineral compositions and proximate analysis of chinese bottle, Lagenaria sciceraria. Electronic J. Eviron. Agric. \& Fd. Chem., 8(7): $534-543$.
Omidiji MO. 1977. Tropical cucurbitaceous oil plants of Nigeria. Vegetables for the Hot Humid Tropics, 2: 37-39.

Oshodi AA, Ipinmoroti KO, Adeyeye EI, Hall GM. 1995. Amino and fatty acids composition of African yam bean (Sphenostylis stenocarpa) flour. Food Chem., 53: 1-6.

SAS. 1987. SAS/STASt. Guide for Personal Computers (Version 6. Ed. 1987); 697978.

Silano V, Bansul HC, Bozzini A. 1982. Improvement of Nutritional Qualities of Food Crops : FAO Plant Production and Protection $N^{\circ} 34$. FAO: Rome, Italy.

Weihrauch JL, Posati LP, Anderson BA, Exler J. 1977. Lipid conversion factors for calculating fatty acid content of foods. Journal of American Oil Chemist Society, 54(1): $36-40$. 